\title{
Turkish Terrorism Studies: A Preliminary Assessment*
}

\author{
Cenker Korhan Demir \\ Gendarmerie and Coast Guard Academy \\ Engin Avc1 \\ Gendarmerie and Coast Guard Academy
}

\begin{abstract}
This article aims to determine the academic disciplinary condition of Turkish terrorism studies in comparison to international ones. We first examine contemporary international terrorism studies and new trends, and then longitudinally assess Turkish terrorism studies via context and methodology. Last, we discuss how and through which perspectives the Turkish discipline could improve and thus contribute to the contemporary literature. We generated three datasets after examining theses, dissertations, and articles. Further, we conducted interviews with and administered questionnaires to terrorism experts to interpret the dataset findings. Regarding context, the most striking point of the Turkish research field is its multi-disciplinary character; because of this fact, Turkish terrorism studies tend to neglect the broader field's terminology and theoretical accumulation. Regarding methodology, a significant problem in the terrorism studies in Turkey is that studies are mostly composed of literature reviews rather than empirical research, thus there is much opportunity for development.
\end{abstract}

Keywords: Turkish terrorism studies, academic discipline, methodology, context, dataset

\section{Introduction}

Although terrorism was a research subject before the attacks on $11^{\text {th }}$ of September 2001 $(9 / 11)$, researchers have paid more attention to the discipline since then. With the more-recent Madrid, London, and Istanbul bombings, terrorism studies have gathered momentum and, as Shepherd says, entered the "golden age" of research. ${ }^{1}$ Moreover, many researchers have carried out seminal reviews on academic pieces of terrorism. One such scholar, Alex Schmid, has searched concepts, theories, databases, and literature. ${ }^{2}$ Silke has examined problems in terrorism studies, particularly from the methodological and conceptual perspectives. ${ }^{3}$

\footnotetext{
Dr. Cenker Korhan Demir, Gendarmerie and Coast Guard Academy, Security Sciences Institute, Ankara, Turkey. Email: ckdemir@gmail.com (correspondence author). Dr. Engin Avc1, Gendarmerie and Coast Guard Academy, Security Sciences Institute, Ankara, Turkey. Email: engavci@gmail.com.

"This article is an extended and updated version of our paper, presented at VII. Conference on International Relations Studies and Education, held by the Council of International Relations and Yasar University on 28th April, 2016.

1 Jessica Shepherd, "The Rise and Rise of Terrorism Studies," The Guardian, July 3, 2007, accessed March 11, 2016, http:// www.theguardian.com/education/2007/jul/03/highereducation.research.

2 Alex P. Schmid, Political Terrorism: A Research Guide to Concepts, Theories, Data Bases and Literature (Amsterdam: North-Holland Publishing, 1984).

3 Andrew Silke, ed., Research on Terrorism: Trends, Achievements and Failures (London: Frank Cass, 2004).
} 
Another study, which is a successor to previous works ${ }^{4}$, encompasses multiple subjects such as definitions, typologies, theories, databases, secondary sources, and literature, and includes a bibliography of terrorism. ${ }^{5}$

Further, there are myriad of articles considering research on terrorism from all aspects, such as content, methodology, databases, and data-analysis techniques. ${ }^{6}$ Methodological discussions and state situations stand out as major issues in the field. For example, Silke notes that terrorism studies have gained only incremental improvements in methodology. ${ }^{7}$ More-recent critical terrorism studies discuss a new approach regarding the epistemological and ontological problems in terrorism studies. ${ }^{8}$ It is clearly recognized that terrorism has drawn the attention of scholars worldwide.

Reviews of context and methodological perspectives have contributed to the knowledge accumulation in the terrorism domain. These kinds of studies are necessary academic endeavours because they facilitate the determination of boundaries of the field, crystallization of the concepts discussed, and exploration of appropriate research methods. These reviews help reveal the challenges encountered in the academic field so that the discipline can further develop.

However, despite the the fact that terrorism has been a major aspect of Turkey's political environment since the early 1960s, there is no comprehensive research examining Turkish terrorism studies ${ }^{9}$ in particular. This article aims to fill this gap by examining Turkish academic studies and views on the subject of terrorism with respect to their context and methodology. Therefore, the research was conducted through an exploratory perspective, seeking to find out the condition of Turkish terrorism studies compared to international work.

This article is divided into two main parts. In the first part, we examine contemporary international terrorism studies and new trends, discussing conceptual and disciplinary matters and then methodological achievements and challenges. In the second part, we assess terrorism studies in Turkey longitudinally perspective via context and methodology. We employed primary and secondary data sources, along with qualitative and quantitative analysis techniques, to reveal and evaluate the academic knowledge related to Turkish terrorism studies. We generated three different datasets for this purpose. First, we coded master's theses and doctoral dissertations registered with the Turkish Higher Education Council (Yüksekögretim Kurulu, YÖK) Thesis Center since $1985 .{ }^{10}$ Second, we classified

4 Silke, Research on Terrorism; Alex P. Schmid and Albert J. Jongman, Political Terrorism: A New Guide to Actors, Authors, Concepts, Data Bases, Theories, and Literature (London: Transaction Publishers, 1988).

Alex P. Schmid, ed., The Routledge Handbook of Terrorism Research (London: Routledge, 2011).

6 See, for example, Ted Robert Gurr, "Empirical Research on Political Terrorism: The State of the Art and How It Might Be Improved," in Current Perspectives on International Terrorism, eds. R.O. Slater and Michael Stohl (London: Macmillan, 1988), 115-54; Martha Crenshaw, "Current Research on Terrorism: The Academic Perspective," Studies in Conflict and Terrorism 15, no. 1 (1992): 1-11; Andrew Silke, "The Devil You Know: Continuing Problems with Research on Terrorism," Terrorism and Political Violence 13, no. 4 (Winter 2001): 1-14; Jeffrey Ian Ross, "Taking Stock of Research Methods and Analysis on Oppositional Political Terrorism," The American Sociologist (Summer 2004): 26-37.

7 Andrew Silke, "The Impact of 9/11 on Research on Terrorism," in Mapping Terrorism Research: State of the Art, Gaps and Future Direction, ed. Magnus Ranstorp (London: Routledge, 2006),89-90.

8 See Richard Jackson, Marie Breen Smyth, and Jeroen Gunning, eds., Critical Terrorism Studies: A New Research Agenda (London: Routledge, 2009); Magnus Ranstorp, ed., Mapping Terrorism Research: State of the Art, Gaps and Future Direction (London: Routledge, 2006); Joseba Zulaika, "Drones, Witches and Other Flying Objects: The Force of Fantasy in US Counterterrorism," Critical Studies on Terrorism 5, no. 1 (2012): 51-68.

9 Doctoral dissertations, master's degree theses, and academic articles written by Turkish scholars/researchers were operationally defined as "Turkish terrorism studies," and covered in this study.

${ }^{10}$ Dissertations about terrorism were extracted from Turkey's National Thesis Database by searching key words selected by the researchers. The terms "terrorism," "terror," "PKK," "Hezbollah," "DHKP-C," "TIKKO," "El Kaide," "HAMAS," and "ASALA" were used to access and select dissertations. Kurdistan Workers Party (Partiya Karkerên Kurdistanê (PKK)), Turkish Hezbollah, 
articles about terrorism published in academic journals according to their research purpose and methodology. ${ }^{11}$ Third, we conducted semi-structured interviews ${ }^{12}$ with 31 academics, and asked them to fill out a questionnaire comprising eight open-ended questions and four list- and scale-type questions, which we developed based on the literature review and a pilot study. ${ }^{13}$ We then analyzed all the information except for the interviews via descriptive statistics and content analysis, and analyzed the data generated by the interview questions through content and discourse analysis.

\section{Contemporary Terrorism Studies: The Evolution of a Research Field}

The evolution of studies on terrorism can be understood through five stages. The first stage is commonly accepted to be the appearance of a new academic research topic between 1960 and 1969. Although terrorism was perceived as a sub-form of political violence rather than a stand-alone research subject, scholars such as Crozier, Thornton, and Walter conducted some seminal research on terrorism in this period. ${ }^{14}$ This era can be recognized as preparation for emergence of the field as a bona fide discipline.

The second stage of terrorism studies, which took place from 1970 to 1978 , is considered by some scholars as the launch or emergence of the field. ${ }^{15}$ It was the most productive era, with $40 \%$ of all publications until 1990 generated during this period. ${ }^{16}$ Additionally, researchers, academics and professionals with a military or intelligence background doubled in numbers in these years. According to Schmid, terrorism was by then conceptualized as a "sui-generis" subject rather than as a sub-category of political violence, armed conflict, guerilla warfare

Workers and Peasants of Turkey (Türkiye İş̧̧i ve Köylü Komünist Ordusu (TIKKO)), El Kaide, HAMAS, and Armenian Secret Army for the Liberation of Armenia (ASALA) are the most effective and aggressive terrorist organizations in the history of terrorism in Turkey. Doctoral dissertations available online were included in the study, but some were restricted by their authors, and thus inaccessible ones could not be examined in detail.

11 Two types of academic journals were examined for the research purposes. First, those indexed in the TR Dizin Social and Humanities Sciences Database (SHSD) were studied. TR Dizin SHSD is a Turkish academic journal index designed by TUBITAKULAKBIM (Türkiye Bilimsel ve Teknolojik Araștırma Kurumu-Ulusal Ăg ve Bilgi Merkezi, the Scientific and Technological Research Council of Turkey-Turkish Academic Network and Information Center). The other data source was internationally indexed journals, which were found in a "Web of Knowledge" search. Once the articles were located by the same keywords used in the dissertations, pieces written by Turkish scholars were selected. Journals without online access, published for a temporary period, or only published in hard copy were not examined.

1231 academics (three female and 28 male) took part in this study. Seven professors, nine associate professors, six assistant professors, and nine lecturers/freelance researchers $(\mathrm{PhD})$ were contacted for the questionnaire and interview using the snowball technique. Most participants (74\%) are teaching fellows at universities and $26 \%$ are officers at military institutions/organizations or freelance lecturers at state institutions. Except for three, most participants have at least one academic experience in terrorism studies, such as authoring a doctoral dissertation, as an advisor, author of an article, book, or book chapter, or teaching a course on terrorism (nine doctoral dissertation authors, one associate professor dissertation author, 14 advisors for theses and dissertations, 23 article authors, and 11 terrorism lecturers.). We note that the interviews and questionnaire were halted after reaching a saturation point of 31 participants. For discussions about validity and the saturation point in qualitative inquiry, see John W. Creswell and Dana L. Miller, "Determining Validity in Qualitative Inquiry," Theory into Practice 39, no. 3 (2000): 124-30; Greg Guest, Arwen Bunce, and Laura Johnson, "How May Interviews Are Enough? An Experiment with Data Saturation and Variability," Field Methods 18, no. 1 (2006): 59-82.

13 The pilot study was conducted with 10 doctoral candidates from the Turkish Military Academy Defense Sciences Institute (Kara Harp Okulu Savunma Bilimleri Enstitüsü, SAVBEN) and the Turkish War Colleges Strategic Research Institute (Harp Akademileri Stratejik Araștırmalar Enstitüsü, HARPAK SAREN).

${ }_{14}$ Brian Crozier, The Rebels (London: Chatto and Windus, 1960); Thomas P. Thorton, "Terror as a Political Agitation," in Internal War: Problems and Approaches, ed. Harry Eckstein (New York, The Free Press of Glencoe, 1964), 71-91; Eugene V. Walter, "Violence and the Process of Terror," American Sociological Review 29, no. 2 (Spring 1964): 48-257.

${ }_{15}$ Edna O. F. Reid, "Evolution of a Body of Knowledge: An Analysis of Terrorism Research," Information Processing and Management 33, no. 1 (1997), 96; Lisa Stampnitzky, Disciplining Terror (Cambridge: Cambridge University Press, 2013); Alex P. Schmid, "Comments on Marc Sageman's Polemic 'The Stagnation in Terrorism Research'," Terrorism and Political Violence 26, no. 4 (2014): 587-95.

${ }_{16}$ Reid, "Evolution of a Body," 96; Avishag Gordon, "Terrorism and Knowledge Growth: A Databases and Internet Analysis," in Research on Terrorism: Trends, Achievements and Failures, ed. Andrew Silke, (London: Frank Cass, 2004), 110. 
or insurgency. ${ }^{17}$ However, developments in the research field did not occur by coincidence but by rising terrorist attacks, perpetrated particularly in Europe from the end of the 1960s onwards. After 1978, studies on terrorism levelled out.

As Reid contends, this stabilization occurred between 1979 and 1985, with a linear growth in publications and increasing specialization among researchers. ${ }^{18}$ The decline of most radical left-wing groups in the West and the end of the Cold War engendered a relative decline in international terrorism studies. ${ }^{19}$ The fourth stage, from 1986 to 1990, is considered a crisis in terrorism literature,$^{20}$ since publications and membership in academic communities also declined as well as reduction of funds. Indeed, as Silke notes, there were only 100 researchers around the world researching and writing continuously on terrorism in this period. ${ }^{21}$

After 9/11, due to the vigorous reaction of the United States, studies on terrorism and counter-terrorism have escalated; ${ }^{22} 150$ books on terrorism were published in one 12-month period, ${ }^{23}$ and at least one book has been published every six months since. ${ }^{24}$ Another study notes that over half of academic articles published between 1971 and 2003 were in the years 2001 and $2002,{ }^{25}$ and peer-reviewed articles increased about $300 \%$ in those two years. ${ }^{26}$

Further, courses and modules on terrorism and terrorism studies programs have begun at virtually every major university at the graduate and postgraduate levels. A growing numbers of doctoral researchers have been undertaking their dissertations on terrorism-related topics. ${ }^{27}$ In addition, the number of centers, organizations, institutes, programs, networks, and projects that seek to expand the research community's collective knowledge of terrorism and related subjects has risen. ${ }^{28}$ This era has been the most productive to date for terrorism studies.

As an indication of rising interest in the research field, many peer-reviewed academic journals have been publishing periodically on terrorism or related subjects since the second era. Among them, Terrorism (1977-1991) and Studies in Conflict and Terrorism (SCT; 1977) commenced its publications at the end of the second era, Terrorism and Political Violence (TPV; 1989- ) in the fourth, and Critical Studies on Terrorism (CST; 2008- ) in the fifth. Other academic journals such as International Security, Journal of Conflict Resolution, Journal of Peace Research, Security Dialogue, and American Political Science Review publish a broad range of topics with the addition of terrorism-related subjects.

The field of study, drawing scholars and practitioners from varied areas, however, has been facing essential challenges. One such challenge is the interdisciplinary character of the field, while another is related to its conceptual fragmentation.

\footnotetext{
17 Alex P. Schmid, "The Literature on Terrorism," in Schmid, The Routledge Handbook, 459.

18 Reid, "Evolution of a Body".

9 Schmid, "The Literature on Terrorism," 459.

Reid, "Evolution of a Body".

1 Silke, "The Devil You Know".

Silke, "The Impact of 9/11," 89-90.

3 Silke, "The Devil You Know".
}

There were just 1,310 books on terrorism before September 2001, but 2,281 books were published between 2001 and 2008 See, Andrew Silke, "Contemporary Terrorism Studies: Issues in Research," in Richard Jackson et al., Critical Terrorism Studies, 34.

${ }^{25}$ Cynthia Lum, Leslie W. Kennedy, and Alison Sherley, "Are Counter-Terrorism Strategies Effective? The results of the Campbell systematic review on counter-terrorism evaluation research," Journal of Experimental Criminology 2, no. 4 (2006): 491.

${ }_{26}$ Pete Lentini, "Review Essay-Understanding and Combatting Terrorism: Definitions, Origins and Strategies," Australian Journal of Political Science 43, no. 1 (2008): 133.

27 Richard Jackson, "The Study of Terrorism 10 Years after 9/11: Successes, Issues, Challenges," Uluslararası Iliş̧kiler 8, no. 32 (2012): 1-16.

${ }_{28}$ Benjamin Freedman, "Terrorism Research Centres: 100 Institutes, Programs and Organisations in the Field of Terrorism, Counter-Terrorism, Radicalisation and Asymmetric Warfare Studies," Perspectives on Terrorism 4, no. 5 (2010), accessed May 13, 


\subsection{Terrorism as an interdisciplinary research field}

Although the figures on terrorism research are encouraging, there is ongoing debate about whether it meets the requirements for a stand-alone academic discipline. For a field to be considered a discipline it must have its own researchers, department, curriculum, products, concepts, and theories. An academic research field that does not meet these criteria could be classified as inter-disciplinary or multi-disciplinary.

Defining the field of terrorism as multi-disciplinary has some flaws. Academics from other disciplines may not have commonalities with terrorism researchers, and the former reflect their own disciplines' perspectives and contexts when explaining terrorism issues. Defining the field as inter-disciplinary may be a better approach; even though experts studying a terrorism topic would be from different academic disciplines, a certain amount of integration is possible over topics, concepts, and methodologies. ${ }^{29}$

Some researchers argue that terrorism research has the characteristics of a stand-alone academic discipline. According to Jackson, the field is considered to have consistent shared assumptions, narratives, and labels about the definition, nature, effects, threat, causes of terrorism, and responses to it. ${ }^{30}$ Schmid supports this notion by arguing that, despite its shortcomings, terrorism studies has matured. He asserts that a fairly solid body of consolidated knowledge has emerged, and that many researchers in the field have great integrity. ${ }^{31}$

However, according to a study that examined articles in TPV and SCT for the years 19901999, the backgrounds and specializations of authors are mostly aggregated in the discipline of political science $(48.6 \%)$. There is also a considerable number of government officials $(9.6 \%)$, military (3.3\%), and law enforcement personnel (2\%), adding up to almost $15 \%$ of authors. ${ }^{32}$ This makeup is not surprising because the terrorism field needs people in hybrid careers. ${ }^{33}$ Practitioners' contributions should not be overlooked because, as Sageman claims, "we have a system of terrorism research in which intelligence analysts know everything but understand nothing, while academics understand everything but know nothing." ${ }^{34}$ This comment reveals the importance of collaboration between academics and practitioners.

Another issue on the terrorism studies field arises from authors' academic background and experience. Many do not have an adequate experience in the field, as there is no barrier to entry. ${ }^{35}$ There are more non-academic contributions in terrorism journals than in journals of political science or communication studies. ${ }^{36}$ For example, a study covering published articles in the 1990 s notes that first-time authors wrote $83 \%$ of the articles. ${ }^{37}$ Similarly, Stampnitzky draws attention to the fact that "of 1,796 individuals presenting at conferences on terrorism between 1972 and 2001, 1,505 (84\%) made only one appearance." ${ }^{\prime 38}$ There is no continuity in

\footnotetext{
29 Ersel Aydınlı, Erol Kurubaş, and Haluk Özdemir, Yöntem, Kuram, Komplo: Türk Uluslararası İlişkiler Disiplininde Vizyon Arayışları (Ankara: Asil Yayın Dă̆ııım, 2009), 28-30.

30 Richard Jackson, "Knowledge, Power and Politics in The Study of Political Terrorism," in Jackson, Critical Terrorism Studies, 66

31 Schmid, "The Literature on Terrorism," 470.

32 Silke, "The Devil You Know".

3 Stampniztky, "Disciplining an Unruly Field".

34 Marc Sageman, "The Stagnation in Terrorism Research,” Terrorism and Political Violence 26 (2014): 565-80.

5 Stampniztky, "Disciplining an Unruly Field".

36 Avishai Gordon, "Terrorism and the Scholarly Communication System," Terrorism and Political Violence 13, no. 4 (2001): 116-24.

37 Silke, "The Devil You Know".

38 Stampnitzky, "Disciplining an Unruly Field".
} 
terrorism studies,${ }^{39}$ and researchers have not preferred it as a major research field. ${ }^{40}$ Further, experts have complained that the field is filled with self-proclaimed experts because there is little regulation about who can be accepted as a specialist. ${ }^{41}$

Indeed, the problem of terrorism needs to be elaborated through different perspectives on levels of analysis such as individual, group, state, and international system. Each level has its own approach to understand the causes of terrorism and employ effective countermeasures. Therefore, terrorism studies have been affected by many academic disciplines, including political science, international relations, sociology, psychology, economy, history, and organizational and management studies. ${ }^{42}$

It is very difficult to situate terrorism studies within only one academic discipline, and further, examining terrorism and related issues in a single discipline may generate some interpretation problems. As Toros and Gunning point out, due to the problem of fetishization, terrorism cannot be understood apart from the context in which it emerged and developed. ${ }^{43}$ The field's interdisciplinary character reflects its nature, which is realized by analyzing various disciplines' concepts and theories. Hence, the phenomenon of terrorism needs to be studied thoroughly in order to reach an integrative approach that comprises all aspects of the considered disciplines.

\subsection{The conceptual fragmentation of terrorism}

Stampniztky argues that prominent authors in terrorism studies have not been able to define the field's concepts nor delineate the boundaries. ${ }^{44}$ Crenshaw states that the lack of agreement on the definition of terrorism, difficulty in creating a comprehensive theory, and having too much event-based research are essential problems that the field faces ${ }^{45}$ Confirming the definitional problem, Gurr draws attention to speculative interpretations and the problems in developing standard prescriptions for counter-terrorism..$^{46}$

Although many in academic ${ }^{47}$ and governmental ${ }^{48}$ circles have tried to define terrorism, there is no agreement and, indeed, a large chasm among the suggestions. Elements of the definition differ; governments and organizations focus on the criminal character of terrorism

39 Avishag Gordon, "Transient and Continuant Authors in a Research Field: The Case of Terrorism," Scientometrics 72, no. 2 (2007); Avishag Gordon, "Terrorism as an Academic Subject after 9/11: Searching the Internet Reveals a Stockholm Syndrome Trend," Studies in Conflict and Terrorism 28, no. 1 (2005): 49.

40 Ariel Merari, “Academic Research and Government Policy on Terrorism,” Terrorism and Political Violence 3, no. 1 (1991): 193-202.

41 Stampnitzky, "Disciplining an Unruly Field".

42 Cenker Korhan Demir, Sebeplerinden Mücadele Yöntemlerine Etnik Ayrllıkç Terörizmin Analizi: PIRA, ETA, PKK (Ankara: Nobel Akademik Yayıncılık, 2017): 99-146.

43 Toros and Gunning, "Exploring a Critical Theory Approach to Terrorism Studies," 98.

44 Lisa Stampnitzky, "Disciplining an Unruly Field: Terrorism Experts and Theories of Scientific/Intellectual Production," Qualitative Sociology 34, no. 1 (2010): 1-19.

45 Martha Crenshaw, "The Psychology of Terrorism: An Agenda for the 21st Century," Political Psychology 21, no. 2 (2000): 405-20. According to her, the study of terrorism goes beyond a concentration on current events. Crenshaw, "The Psychology of Terrorism", 415.

46 Gurr, "Empirical Research".

47 See, for example, Brian Crozier, The Rebels (Boston: The Beacon Press, 1960); Thomas P. Thornton, "Terror as a Weapon of Political Agitation," in Internal War: Problems and Approaches, ed. Herry Eckstein (New York: The Free Press, 1964); Paul Wilkinson, Political Terrorism (London: The Macmillan Press, 1974); Schmid, Political Terrorism.

${ }_{48}$ There are also some efforts at the international organization level. The first efforts, started by the League of Nations, came to naught because the Second World War erupted. After the war, the Ad Hoc Committee on International Terrorism was established by a United Nations General Assembly (GA) resolution in 1972, with a subcommittee on defining terrorism. The committee developed a draft definition, and the GA staged discussions about it but came to no agreement. 
while academics focus on its political character. ${ }^{49}$ Indeed, in academic studies, the political element of terrorism is the most-featured characteristic after violence. ${ }^{50}$

Moreover, there is a dearth of conceptual studies; only eight articles have been published between 1990 and $1999^{51}$ and seven articles between 2000-2007..$^{52}$ One of the underlying causes of this problem stems mainly from the contestation of ideologies and political objectives. ${ }^{53}$ There is no act of violence that is in and of itself deemed to be inherently terrorist, and terrorism is a method used by variety of actors. ${ }^{54}$ Moreover, the modern meaning of terrorism is pejorative, especially after "second wave" of terrorism. ${ }^{55}$ Further, despite the fact that almost all goverments and international organizations condemn terrorism, no organization calls itself 'terrorist,' and there may be little agreement between states whether a particular organization is 'terrorist' or not.

Since terrorism is a political subject and some governments and international organizations have differing (and competing) interests, there is also no universally recognized terrorist organization list. Therefore, it can be stated that although there is no agreement on the definition of terrorism, there is agreement that there is no commonly accepted definition of terrorism.

Because of this conceptual fragmentation, it has been noted that terrorism studies is a static environment, where the same ideas, definitions, hypotheses, and theories continue to be analyzed, assimilated, published, cited, and publicized by the media. ${ }^{56}$ Although there is considerable amount of publication in the field, Schmid complains that much of it is "impressionistic, superficial, and at the same time often also pretentious, venturing farreaching generalizations on the basis of episodal evidence." ${ }^{57}$

It is contended that a lack of self-reflexivity and contextualization, ahistoricity, statist bias, and a dearth of fieldwork are among the essential problems of the field. ${ }^{58}$ Avishag Gordon calls terrorism research a "multi-paradigmatic research field," 59 and Reid and Chen confirm this finding by stating that the intellectual infrastructure of contemporary terrorism studies has been influenced by studies on conflict, foreign policy, regional issues, and political violence. ${ }^{60}$ The problems over the field's definitional and disciplinary aspects somewhat reflect the methodology as well.

\subsection{Methodological concerns on terrorism research}

Studies on terrorism have been criticized for poor research methodology. Schmid and Jongman have noted that "there are probably few areas in the social science literature in which so much

\footnotetext{
49 Alex P. Schmid, "The Definition of Terrorism," in Schmid, The Routledge Handbook, 75.

50 See, Schmid, Political Terrorism, 4-25; Leonard Weinberg, Ami Pedahzur, and Sivan Hirsch-Hoefler, "The Challenges of Conceptualizing Terrorism," Terrorism and Political Violence 16, no. 4 (2004): 781. Former one consists of 22 elements drawn from 109 definitions while later consists of 19 elements drawn from 55 articles.

51 Andrew Silke, "The Road Less Travelled: Recent Trends in Terrorism Research," Andrew Silke, ed., Research on Terrorism: Trens Achievements and Failures (London: Frank Cass, 2004), 207.

52 Magnus Ranstorp, "Mapping Terrorism Studies After 9/11: An Academic Field of Old Problems and New Prospects," in Jackson et al, Critical Terrorism Studies, 23.

53 Schmid, "The Definition of Terrorism," 42.

54 Anthony Richards, “Conceptualizing Terrorism," Studies in Conflict \& Terrorism 37, no. 3 (2014), 213-36.

55 David C. Rapoport, "The Four Waves of Rebel Terror and September 11," in The New Global Terrorism, ed. Charles Kegley (New Jersey: Pearson, 2008), 41.

56 Reid, "Evolution of a Body".

57 Schmid, Political Terrorism, 418.

58 Toros and Gunning, "Exploring a Critical Theory," 87.

59 Avishag Gordon, "Can Terrorism Become a Scientific Discipline? A Diagnostic Study," Critical Studies on Terrorism 3, no. 3 (2010): 437-58.

60 Edna Reid and Hsinchun Chen, "Domain Mapping of Contemporary Terrorism Research," in Terrorism Informatics: Knowledge Management and Data Mining for Homeland Security, eds. H. Chen, E. Reid, J. Sinai, A. Silke and B. Ganor (New York: Springer, 2008), 3-26.
} 
is written on the basis of so little research. Perhaps as much as $80 \%$ of the literature is not research-based in any rigorous sense." ${ }^{\prime 61}$ Terrorism articles in peer-reviewed journals between 1971 and 2003 are considered mostly "thought pieces," theoretical discussions, or opinions; only about $3 \%$ of them employ some kind of empirical analysis. ${ }^{62}$ Many researchers are often poorly aware of what has already been done in the field and are naïve in their methods and conclusions. ${ }^{63}$

One of the causes of methodological weakness is to employ secondary sources widely, such as scholarly books and articles, media and news services, open government documents, and records originating from terrorists/sympathizers. ${ }^{64}$ Sageman concurs with these arguments by implying that terrorism research has stagnated because of the lack of primary sources and vigorous efforts to police the quality of research. ${ }^{65}$ Affirming this flaw, it is argued that no new data or knowledge has been produced because of the heavy reliance on open-source documents among terrorism researchers. It is pointed out that the $62 \%$ of studies were based on documentary analyses/reviews, while just $1 \%$ were structured and systematic interviews. ${ }^{66}$

It is very difficult for researchers to have reliable and valid information without primary sources. However, reaching sources that meet academic standards is not easy because of the clandestine natures of terrorist organizations. ${ }^{67}$ These impediments, combined with time and funding limitations contribute to the difficulty of gathering empirical evidence.

As a secondary source, event datasets provide information on terrorist-related acts, and according to one study, there are more than 30 such datasets. ${ }^{68}$ This data is beneficial for researchers in learning who perpetrates terrorist acts, types of terrorism, targets of attacks, and changing trends over time. Datasets are also used to test hypotheses in a quantitative manner. ${ }^{69}$

However, there are some difficulties in relying on datasets. Since there is no agreed definition on the concept of terrorism and a lack of reliable sources for gaining information to develop the datasets, researchers are reluctant to rely on the datum in terms of comprehensiveness and reliability. Coding errors, limited or no records of sources, lack of information, unreliable sources, and inherent uncertainty are recognized as problems with credibility and validity. ${ }^{70}$ Further, it is obvious that the governments are not eager to fund research projects or give out information on terrorist-related events because of the concern about researchers uncovering classified information. These roadblocks thus affect the quality of the product.

Another problem with terrorism research is the weak employment of statistical analyses comparing to other social science research fields. ${ }^{71}$ The statistical method, indeed, gives the researcher a useful tool to manage rough and big datasets successfully, and to explain and predict the variables in a causal manner. There is an expanding tendency to use statistical methods in articles appearing in the main terrorism journals, however, there are limitations

${ }^{61}$ Schmid and Jongman, Political Terrorism, 179. Authors imply that they could not find any data on how terrorist acts are committed after examining 6000 studies between 1968 and 1988.

${ }^{62}$ Lum, et al., "Are counter-terrorism strategies effective?" 491-92.

63 Silke, "The Devil You Know".

64 Schmid and Jongman, Political Terrorism, 138; Schmid, Political Terrorism, 11.

65 Sageman, "The Stagnation in Terrorism Research".

66 Silke, "The Devil You Know".

${ }^{67}$ Merari, "Academic Research".

68 Schmid, "Introduction," 10.

69 Ross, "Taking Stock of".

${ }^{70}$ Gary A. Ackerman and Lauren E. Pinson, "Speaking Truth to Sources: Introducing a Method for the Quantitative Evaluation of Open Sources in Event Data," Studies in Conflict \& Terrorism 39, nos. 7-8 (2016): 622- 24.

71 Silke, "The Devil You Know". 
to solely using statistics to understand social phenomena such as terrorism. One limitation is that statistics are usually applied in quantitative analyses more than qualitative. The debate on this classification emanates from the pursuit of achieving objective and scientific knowledge; the main objective of a qualitative study is to describe a situation, phenomenon, problem, or event. ${ }^{72}$ Although it is beyond of the article's scope to discuss this issue in detail, it should be noted that there are ongoing debates about using the two methods in an "analytical eclectic model" ${ }^{\text {"73 }}$ for studying terrorism-related issues. ${ }^{74}$ Given that the main point of any research is to answer the stated research question(s), the most appropriate method and means to do so must be utilized. Thus, the means should not be a substitute for the ends.

There is a new research approach called critical terrorism studies, whose scholars believe that there are epistemological and ontological problems in terrorism studies in addition to the methodological concerns. They feel that the positivist methods used in the research do not reflect the facts of the field. These scholars argue that the most essential issue emerges from the conventional wisdom of Westerners, who try to understand non-Western problems with Western methodologies and points of view. Moreover, Jackson states that since any social researcher cannot analyze independently of his or her culture, values, perception, and identity, the categories or arguments deduced from the field can only be understood as the products and components of the researcher's political-historical background, even though they may not intend to present them this way. ${ }^{75}$ In politics, key terms are often value laden, and appeal to emotions. ${ }^{76}$ As a socially constructed academic subject and as a type of political violence, terrorism studies would be even more open to these kinds of conjectures.

Further, the politics and interests of governments have likely affected terrorism studies. ${ }^{77}$ Silke points out that terrorism is an emotional subject, and it is relatively rare to find objectivity in the field; researchers' work may reflect their feelings about terrorism, similar to any other social field. ${ }^{78}$ Jackson claims that terrorism studies also intrinsically carry political and ideological tendencies, and he adds that terrorism studies cannot be evaluated separately from government ideology. ${ }^{79}$ Indeed, Schmid indicates that political biases and mistaken assumptions can be found in terrorism studies more than in others. ${ }^{80}$ Thus, staying neutral in terrorism research is challenging, particularly when studying domestic terrorism.

As a large number of scholars study terrorism-related subjects, ranging from conceptual issues to theoretical assertions, the research field, gains an avalanche of concern from all perspectives. Prominent examples of this field's wide range of topics are definitional and conceptual attempts, historical perspectives, the exploitation of religion and ethnicity as motivators, terrorist acts as a way of communication, organizational perspectives, the

\footnotetext{
72 Ranjit Kumar, Research Methodology (London: Sage Publications, 1999).

73 The model is proposed by Rudra Sil and Peter Katzenstein. See Rudra Sil and Peter Katzenstein, "Analytical Eclecticism in the Study of World Politics: Reconfiguring Problems and Mechanisms across Research Traditions," Perspectives on Politics 8, no. 2 (June 2010): 411-31.

${ }^{74}$ See Robert Jackson, "Constructing Enemies: 'Islamic Terrorism,' in Political and Academic Discourse," Government and Opposition 42, no. 3 (2007): 394-426; Rainer Hülsse and Alexander Spencer, "The Metaphor of Terror: Terrorism Studies in Constructivist Turn," Security Dialogue 39, no. 6 (2008): 571-92; Nil S. Satana, Molly Inman, and Johanna Kristin Binnir, "Religion, Government Coalitions, and Terrorism," Terrorism and Political Violence 25, no. 1 (2013): 29-52.

75 Richard Jackson, “The Epistemological Crisis of Counterterrorism," Critical Studies on Terrorism 8, no. 1 (2015): 33-54; Stampnitzky, Disciplining Terror

76 Schmid, "The Definition of Terrorism," 41.

77 Ranstorp, "Mapping Terrorism Studies," 24.

78 Silke, "The Devil You Know".

79 Richard Jackson, "Knowledge, Power and Politics in the Study of Political Terrorism," in Jackson et al., Critical Terrorism Studies, 67-8.

80 Schmid, "The Literature on Terrorism," 468.
} 
dynamics of insurgencies and rebellion, social movement theory, democratization and terrorism, psychological approaches to terrorist behavior, counterterrorism methods, and intelligence on terrorism. ${ }^{81}$ However, one of the important problems of contemporary terrorism studies arises from the lack of coordination and regulation of academic efforts and field experience. Notwithstanding the foregoing difficulties faced by terrorism studies, as Schmid argues, there is a fairly solid body of consolidated knowledge, datasets, and wellknown scholars in international terrorism studies. ${ }^{82}$ In this regard, the contemporary terrorism field presents a perspective, which is open to improvement.

After scrutinizing the literature on the evolution of terrorism studies and the methodology employed, it is found that there are three main shortfalls in international terrorism studies. First, the area has not developed its own concepts and theories, and this conceptual fragmentation sparks the discussion on whether terrorism studies is a stand-alone field. The other problem stems from the character of the terrorism field; terrorism studies are intrinsically value laden. Since terrorism is a type of political violence, researchers and officials are not able to detach themselves completely from terrorist events. The last problem consists of methodological concerns: any social research area has challenges with methodological perfection, but terrorism studies seem to experience more than other fields.

\section{Terrorism Studies in Turkey}

This section of the paper explores the situation of Turkish terrorism studies by using the frame drawn by the literature on international terrorism studies, which, to recap, includes the issues of whether the field is its own discipline and its methodological inadequacies.

\subsection{Volume of terrorism studies in Turkey}

Some essential characteristics of an academic discipline can be identified as having accumulated knowledge, departments, and research institutes working in the field. The early sign of this development in Turkey comes out with the beginning of postgraduate programs on terrorism by state- affiliated institutions and colleges after the 2000s. The first postgraduate program on terrorism began in 2002 at the Turkish Military Academy Defense Sciences Institute (Kara Harp Okulu Savunma Bilimleri Enstitüsü, KHO SAVBEN) at the master's degree level under the International Security and Terrorism program, and doctoral education there began in 2006. ${ }^{83}$ Another institution, the Police Academy Security Sciences Institute (Polis Akademisi Güvenlik Bilimleri Enstitüsü), started its postgraduate programs in 2001 and currently has two postgraduate programs: International Security and Security Strategies and Management. ${ }^{84}$ Although there is no other postgraduate program focusing on terrorism, the Turkish War Colleges Strategic Research Institute (Harp Akademileri Stratejik Araştırmalar Enstitüsü, HARPAK SAREN), Sabancı University, TOBB University of Economics and Technology (Türkiye Odalar ve Borsalar Birliği Ekonomi ve Teknoloji Universitesi, TOBB ETU), Istanbul Aydın University, and Istanbul Gelisim University have postgraduate programs on security, conflict resolution, and strategy-related topics.

\footnotetext{
${ }^{81}$ Alex P. Schmid, "Introduction," in Schmid, The Routledge Handbook, 11-2.

82 Schmid, "The Literature on Terrorism," 470.

${ }_{83}$ Kara Harp Okulu Savunma Bilimleri Enstitüsü, accessed April 26, 2016, http://www.kho.edu.tr/akademik /enstitu/enstitu genel_bilgi.html.

${ }^{84}$ Polis Akademisi Başkanlığı Güvenlik Bilimleri Enstitüsü, accessed April 26, 2016, http://www.pa.edu.tr /Default.aspx? pag $\mathrm{e}=$ EgitimBirimleri\&GUID=dc9fb08d-0a56-4861-896e-043125798cc6.
} 
Thanks to the research institutes and programs, masters' theses, doctoral dissertations, and articles on terrorism have burgeoned in Turkey since the 2000s. To date, there are 521 theses and dissertations on terrorism, 446 of which are at the master's level and 75 of which are at the doctoral level. ${ }^{85}$ The types and years of the dissertations and theses are shown in Figure $1 .{ }^{86}$

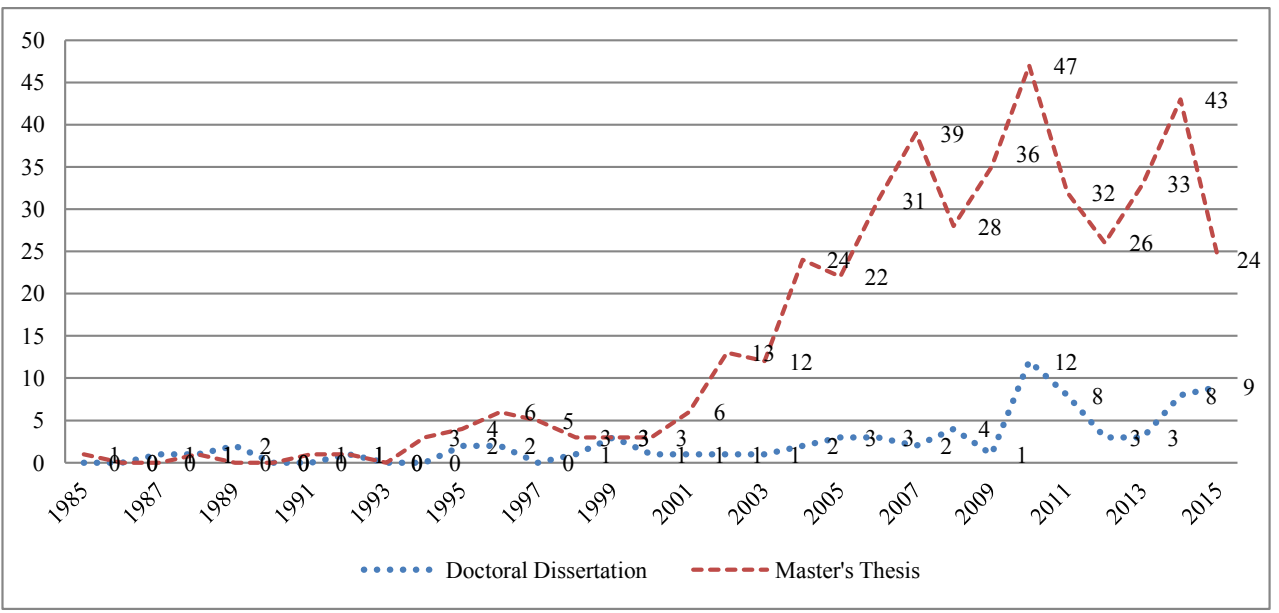

Figure 1: Number of Theses and Dissertations Registered in YOK Theses and Dissertations Database per Year

The first dissertation was registered to the National Thesis Center in 1987. Only 52 theses and dissertations on terrorism (15 doctoral and 37 master's) were registered between 1987 and 2001, and 90\% of total theses (60 doctoral and 409 master's) were recorded after 9/11 attacks. Between the years of 2010 and 2014, during which studies reached their peak numbers, a total of 90 master's theses and 20 doctoral dissertations were written.

We found similar numbers for articles on terrorism. According to data extracted from internationally indexed journals and the journals indexed by TR Dizin Social and Humanities Sciences Database (SHSD), a total of 198 academic articles (112 TR Dizin, 86 internationally indexed journals, Web of Science [WoS]) complying with the aims of this study were found, ${ }^{87}$ as shown in the Figure 2.

${ }^{85}$ National Thesis Center, accessed April 26, 2016, www.tez.yok.gov.tr. Information regarding dissertations extracted from National Dissertation Center was converted into a dataset after a detailed study with quantitative and qualitative techniques by the authors. Findings and analysis about dissertations depend on this dataset.

${ }^{86}$ The figures presented here are descriptive, and to be discussed later in the article.

87 Tübitak-Ulakbim Cahit Arf Bilgi Merkezi, accessed May 21, 2016, http://cabim.ulakbim.gov.tr/tr-dizin/tr-dizindedizinlenen-dergi-listesi/. The internationally indexed journals searched for this article appeared in the Web of Science (WoS), accessed March 30, 2017, https://apps.webofknowledge. com/WOS Advanced Search input.do?SID=N22WtvJkjXmjMMMqA3 v\&product=WOS\&replaceSetId=\&goToPageLoc=SearchHistoryTableBanner\&search_mode=AdvancedSearch\&errorQid=1\#Searc hHistoryTableBanner. The findings have been converted into a dataset similar to the dissertations. 


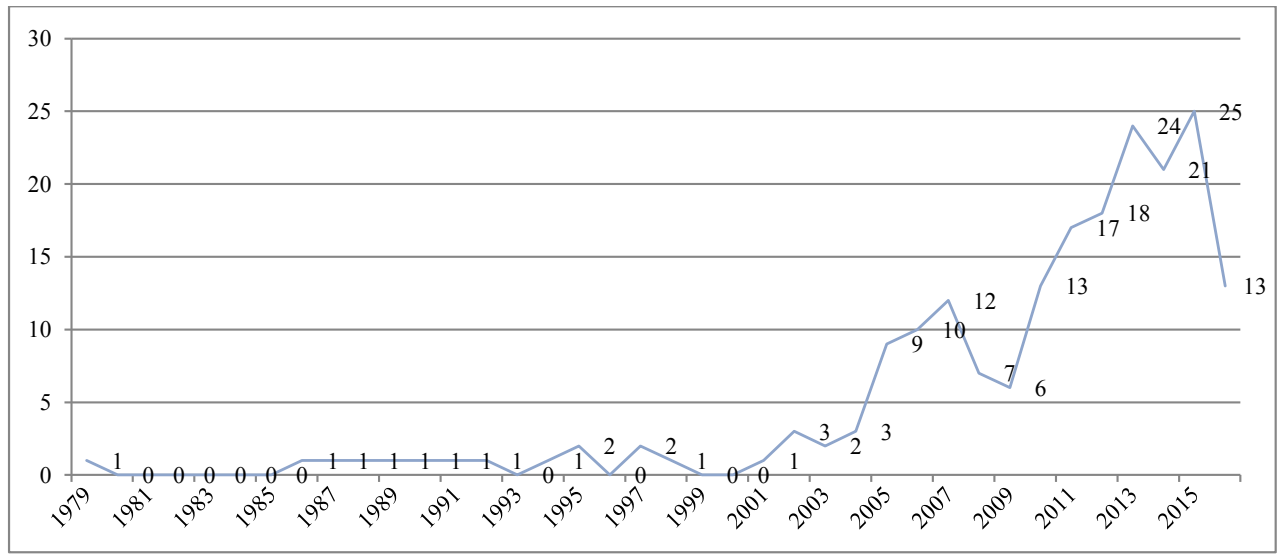

Figure 2: Number of Terrorism Articles Published in Internationally and Nationally Indexed Journals per Year

It is remarkable that between 1979 and 2003 only 20 articles were published in Turkey on terrorism. These numbers began to change in 2004, as depicted in Figure 2, and reached their highest levels in 2013 and 2015. As the compiled dataset shows, 93\% of the articles were published after the 9/11 attacks, which shows the similar trend like the theses and dissertation dataset.

The authors of dissertations and articles share one other essential point. It is found that almost $16 \%$ of articles and $24 \%$ of doctoral dissertations were written by authors who work(ed) for security agencies and state institutions. This finding is supported by an interviewee's statement that "most of the authors are soldiers and law-enforcement officers." This comment implies that state-affiliated academic institutions generate a considerable account of studies, and terrorism-related topics draw the attention of many practitioners in Turkey.

Additionally, there are nearly 30 research centers and think tanks in Ankara and Istanbul studying security, international relations, and global and regional issues. ${ }^{88}$ Most of these institutions were established after the 2000s. Even though all of these centers focus on regional and international security and related issues, and many of them have been publishing monographs and reports on terrorism-related issues since their foundation, only one contains "terrorism" in its title. ${ }^{89}$

\subsection{The question of terrorism as a stand-alone academic field}

Although the academic publications in Turkey on terrorism are relatively numerous, and terrorism studies are now part of undergraduate, graduate, and postgraduate programs at universities and institutions, the academic state of terrorism studies in Turkey is still under debate. In the interviews we conducted, $90 \%$ of participants responded that "terrorism is a study area or subject, not an academic discipline or sub-discipline." Scholars who study this area stated that Turkish terrorism studies is not a stand-alone field, but related to many academic disciplines. This claim is supported by the dataset generated for theses and dissertations (Figure 3).

${ }^{88}$ BILGESAM, ORSAM, TEPAV, TESEV, TESAM and TASAM are the leading think tanks in Turkey. For more information, see http://www.bilgesam.org/en; http://www.tepav.org.tr/en; http://tesev.org.tr/en/; http://www.orsam.org.tr/?c=orsam|english; http:// tesam.org.tr; http://www. tasam.org/en.

${ }^{89}$ International Terrorism and Transnational Crimes Research Center (Uluslararası Terörizm ve Sinıraşan Suçlar Araştırma Merkezi, UTSAM), founded in 2007, changed its name to International Terrorism and Security Research Center (Uluslararast Terörizm ve Güvenlik Araştırma Merkezi, UTGAM) after 2015. See Police Academy Security Sciences Institute (Polis Akademisi Güvenlik Bilimleri Enstitüsü), accessed April 2, 2017, http://www.pa.edu.tr/Default.aspx?page=EgitimBirimleri \&GUID=dc9fb08d- 


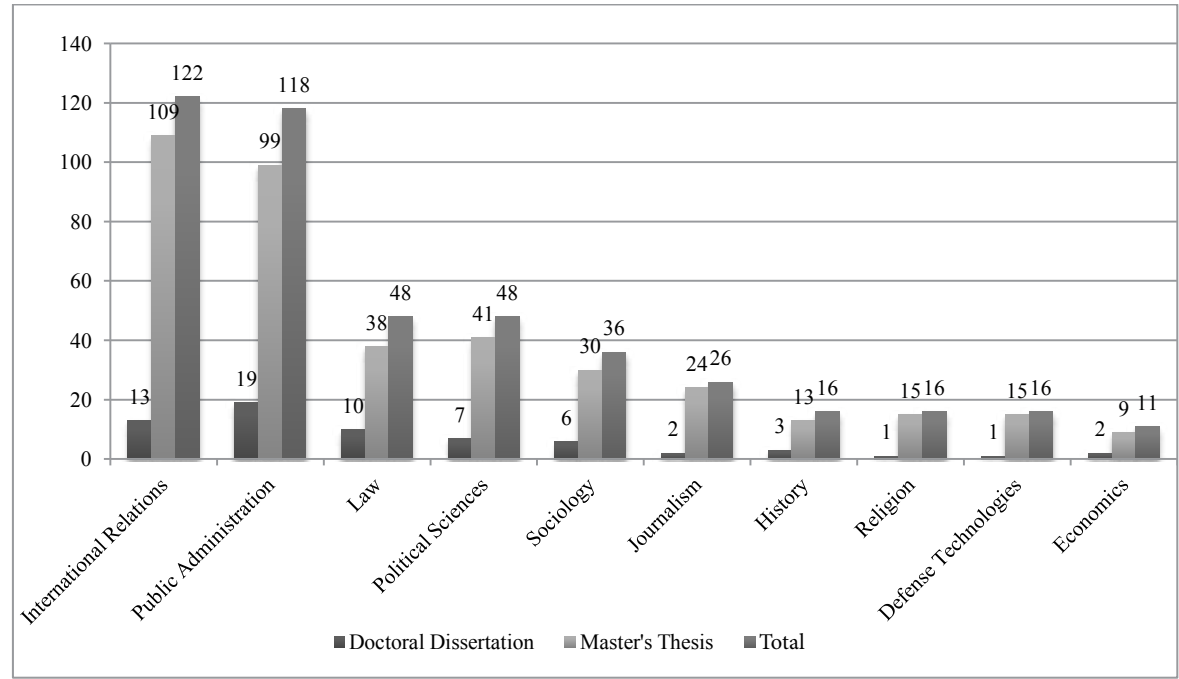

Figure 3: Primary Research Field of Theses and Dissertations Registered in YOK Theses and Dissertations Database 1985-2016

The theses and dissertations we examined at the registry are related to 37 different academic branches, according to the Turkish Higher Education Council. In this context, $76 \%$ of all theses/dissertations (398) are within the scientific branches of International Relations, Public Administration, Political Sciences, Law, Sociology, and Journalism. Almost half (46\%) relate to International Relations and Public Administration.

The 198 articles distribute among 15 disciplines, ${ }^{90} 12$ of which are as shown in Figure 4. Political Sciences leads the classification, with 63 articles, and International Relations follows, with 57 articles. As shown in Figure 3 and Figure 4, Turkish terrorism studies is part of many disciplines, but International Relations, Political Science, Economics, and Public Administration are the top four.

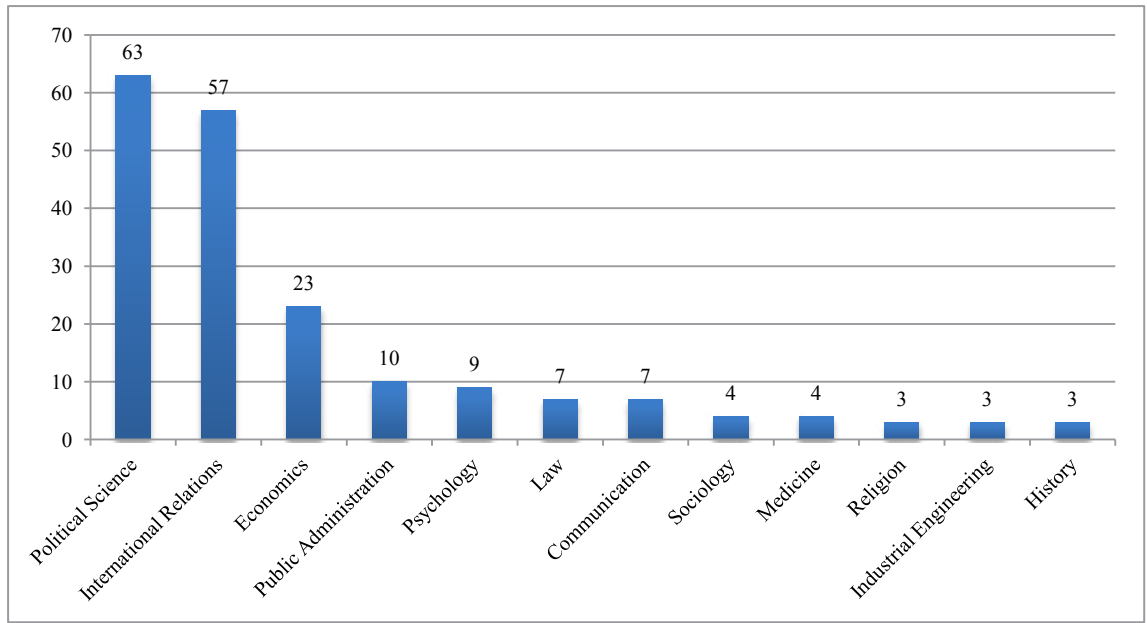

Figure 4: Primary Research Fields of Articles Published in Internationally and Nationally Indexed Journals 1979-2016

\footnotetext{
90 The articles were classified into various disciplines by the authors using content analysis on the abstracts and keywords.
} 
It is also found that the varying topics and disciplines reflected in terrorism research are related to the supervisors of dissertations. After examining the names of the doctoral advisers, we found that one professor supervised 10 dissertations in total, while four professors advised two dissertations each, and 57 lecturers advised only one doctoral dissertation per person. We also note that most of the lecturers supervising doctoral dissertations are (were) PhDs or associate professors in International Relations. The problem of the one-time researcher emerges in the articles dataset as well. In the 198 articles, there are 268 authors (some articles are multi-authored), and only 25 of these authors have written more than one paper. Therefore, it can be argued that not many academics in Turkey are studying and writing regularly on terrorism.

The abovementioned findings and discussions indicate that Turkish terrorism studies draws the attention of academics and staff from varying disciplines, state-affiliated institutions, and government officials. The authors then asked participants the following question: "According to you, of which academic discipline is terrorism a sub-study area or sub-discipline and in which order would you list them?" The findings are shown in Figure 5.

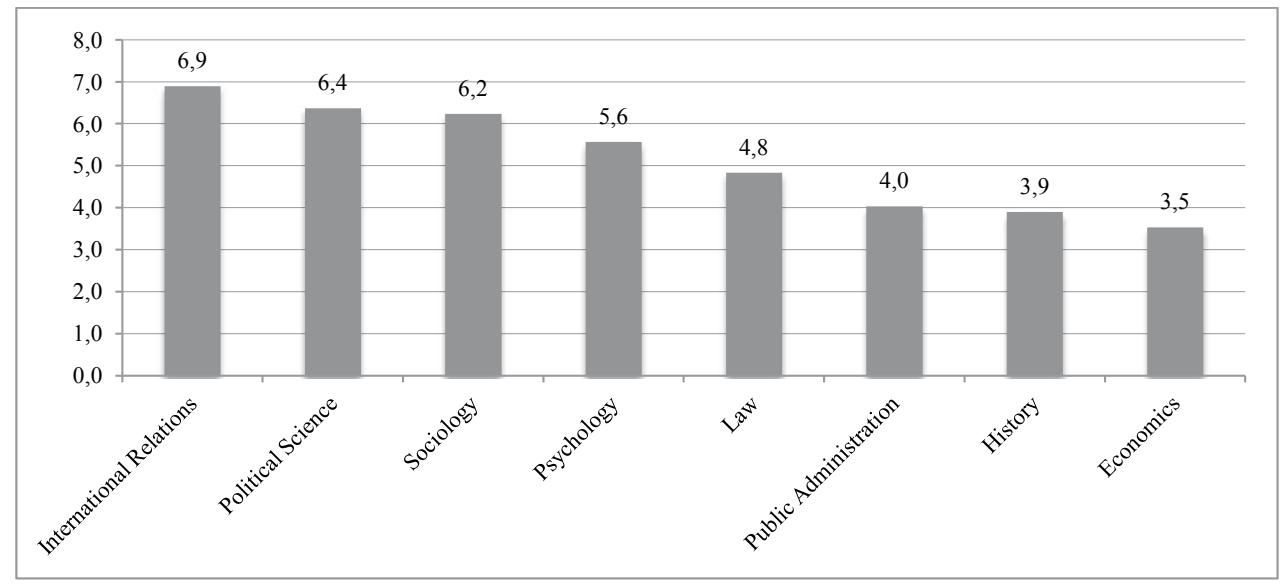

Figure 5: Percentage of Responses Designating Terrorism as Sub-Field of a Discipline

The graph shows that the terrorism field is seen as linked with many disciplines, but most participants feel it is a research topic under International Relations, Political Science, and Sociology, respectively. These findings are also compatible with the dissertation and articles datasets, except for Public Administration and Economics. ${ }^{91}$ A probable reason for these results is that the most participants have academic degrees in International Relations. Another one is that the rigorous methodology of an academic discipline, such as Economics, allowed researchers more opportunity to publish their pieces in peer-reviewed journals despite their lack of knowledge on the context of the particular field. Another possibility is that since the majority of the authors of the theses/dissertations are (were) working in government offices, perhaps they opted to register their document under the Public Administration discipline.

One of the findings reached after analyzing the primary and secondary sources is that terrorism is generally viewed as a sub-field of many scientific disciplines. Our findings

91 Public Administration is the second most-cited academic discipline in the dissertation dataset, but it is in sixth place among the eight academic disciplines in the questionnaire. Economics is the third academic discipline in the article dataset, but is at the 
suggest that Turkish terrorism studies has a multi-disciplinary character; strong evidence of this result can be found in the answers of our survey respondents. For instance, most participants answered the question of "What is the main problem in terrorism studies?" with "insufficient knowledge of the area." The participants accept that terrorism is a (sub)research field, but also state that researchers from many academic disciplines write on terrorism with little knowledge of the basic concepts and theories. Moreover, in Turkey, it should be noted that "terrorism studies" or "terrorism" is not recognized as a field of specialization under any academic discipline in the classifications determined by the Council of Universities (Üniversitelerarası Kurul). This situation is a drawback for researchers who intend to have a career in terrorism studies in particular, because the Council of Universities is the main body establishing the criteria for academic promotions.

\subsection{The value-ladenness of Turkish terrorism studies}

The findings thus far raise some important questions about Turkish terrorism studies. One of them is why the field only expanded after 2001, as the international field did, in spite of the fact that Turkey has been a target for terrorist organizations since the 1960s. Another question arises about the reasons over the fluctuating numbers of theses/dissertations and articles in Figure 1 and Figure 2; 2007, 2010, 2013, 2014 and 2015 have the highest numbers of theses, dissertations, and articles.

One possible explanation for both questions that students with masters or doctoral degrees in the subject graduated from scientific institutions founded since 2000s, and that there has also been an escalation in the numbers of freelance research centers and think tanks in those years. It could also be argued that some scholars and researchers have shifted their academic concerns from other disciplines to terrorism because it became a popular topic after 9/11.

The question of fluctuation was elaborated in the interviews, for example: "Academics abstain from writing about problematic issues because of fear of terrorist organizations or emotional causes; they prefer to write on terrorism-related issues when violent attacks decline and the security situation remains relatively stable." Another participant said that "terrorism is a current problem, and while terrorist organizations are committing their attacks it is very difficult for researchers and editorial boards of the journals...to decide that publishing about terrorism" should be considered.

To determine whether these comments had merit, we compared terrorism attacks in Turkey and the dates of academic publications on the subject. As evident from Figure 6, the most devastating years for terrorist attacks in Turkey were 1977, 1990-1994, 2012, and 2015. ${ }^{92}$ Publications on terrorism by Turkish authors rose through 2007, and were at their lowest levels in 2012 and before the 2000s. Although it seems that there is no relation between terrorist attacks and academic publications, to be sure, we conducted a correlation analysis and could not find a significant correlation $(r=0.01 ; p>0,9)$ between terrorist attacks and Turkish terrorism studies. We repeated the analysis with the lagged values (one and two years) of publications, but it either shows no significant correlation. Therefore, there is no convincing evidence on the relation between terrorist attacks and academic publications.

${ }_{92}$ Number of terrorist attacks in Turkey were retrieved from Global Terrorism Database, accessed March 25, 2017, https:// www.start.umd.edu/gtd/. 


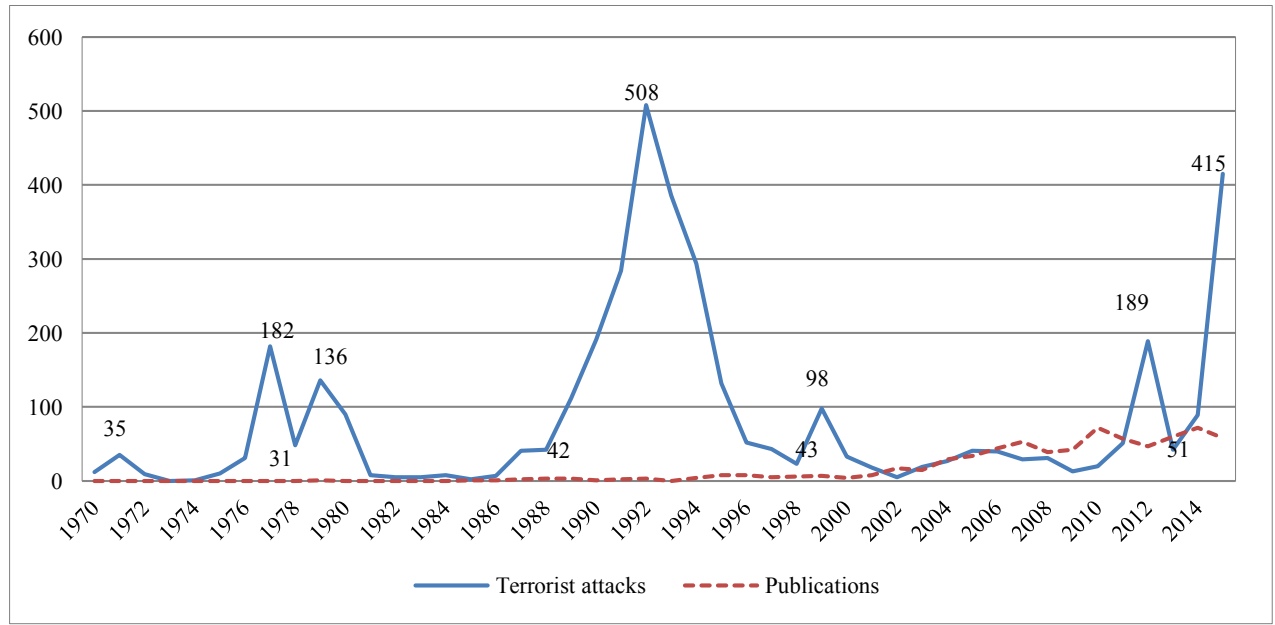

Figure 6: Number of Terrorist Attacks in Turkey and Publications on Terrorism

We also examined the effect of emotional factors on the publications. This possibility was suggested to the participants with the following questions: "Do you think that terrorism studies are affected by the socio-cultural position or thinking style in which the researchers are living? If you compare this issue to the other academic disciplines, is it possible to say terrorism studies are affected by the researchers' social roles more than any other area of social sciences?" $40 \%$ of participants commented that "being impartial in terrorism studies" is very important, but is difficult to do compared with other fields. According to the participants, emotional factors have considerable effect on the neutrality of researchers. Indeed, one of our findings supports this idea: out of 75 dissertations, 31 theses are not accessible in the National Thesis Database because the authors have not given permission for access.

Another indication of the emotions play in research can be found in the publications themselves. In order to grasp the real picture, we examined titles, abstracts and keywords of the dissertations and articles and regrouped them thematically. ${ }^{93}$ Figure 7 shows that doctoral dissertations, mostly focus on terrorism and law, counter-terrorism, terrorism in Turkey, international terrorism, terrorism and media, religion-based terrorism, financing of terrorism, and human rights.

${ }_{93}$ Content analysis was employed in titles, abstracts, and keywords of the dissertations and articles, and the findings were regrouped. 


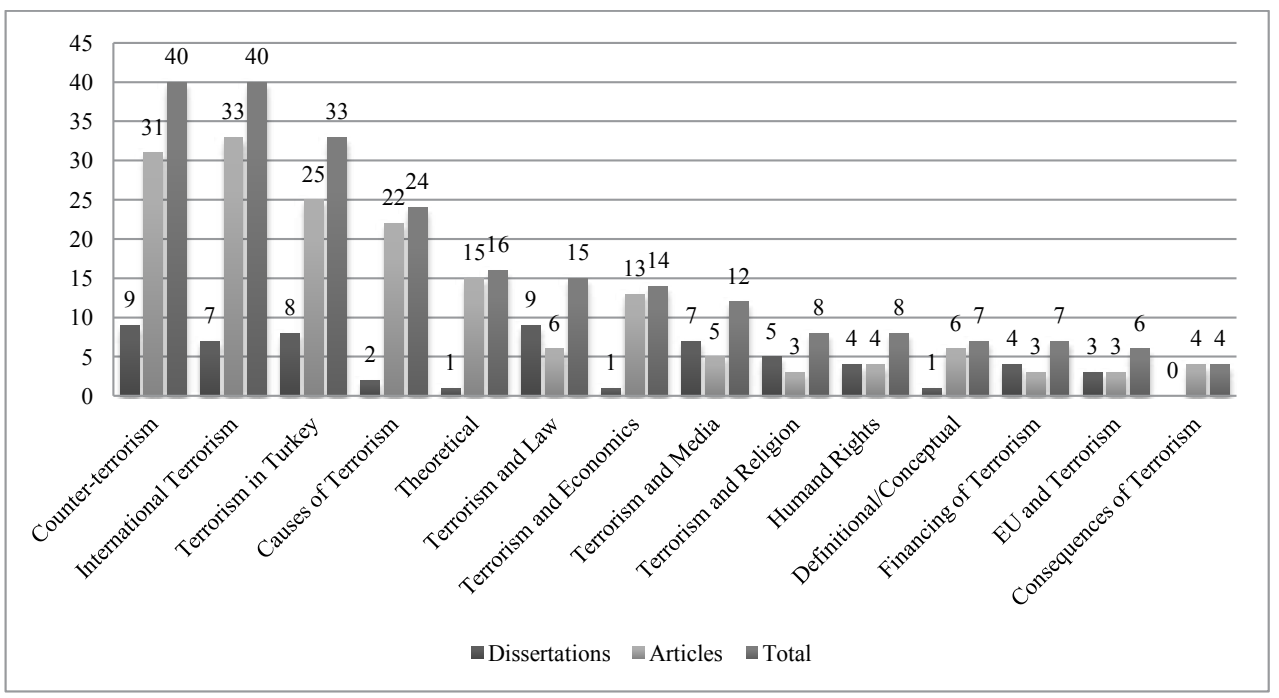

Figure 7: Thematic Codification of Dissertations and Articles

Moreover, most articles focus on counter-terrorism and international terrorism. Terrorism in Turkey and causes of terrorism come second and third (Figure 7). The thematic codification of the titles and abstracts of dissertations and articles indicate that Turkish terrorism research varies widely by topic. However, terrorism in Turkey itself has not been an attractive research field; we found that $52 \%$ of the theses/dissertations and $87 \%$ of the articles do not cover topics related directly to Turkey.

It can be inferred from the above findings that terrorism is not an academic topic that is preferred and studied easily in Turkey. Emotional factors and the value-laden aspect of the subject plays into this finding, but there are also serious methodological issues.

\subsection{Methodology in Turkish terrorism studies}

Research can be conducted via varying methodological perspectives. For example, Kumar classifies perspectives into three types: applications of the research study, objectives of the study, and type of information sought in the study. ${ }^{94}$ In another study, research approaches are categorized as follows: basic philosophy, objective, methodology, period of study, and unit of analysis.$^{95}$ For the purposes of this study, we categorized the theses/dissertations and articles into objectives, data collection tools, and data analysis techniques. In this context, the study objectives consist of descriptive, explanatory, and exploratory questions; ${ }^{96}$ the tools for data collection were the questionnaire, observations, interviews, life stories, judicial documents,

94 There are two broad categories, pure research and applied research, depending on the perspective of its application. Research objectives can be classified as descriptive, correlational, explanatory, or exploratory. The third perspective in Kumar's typology is related to mode of enquiry, which are structured and unstructured approaches, and are usually classified into quantitative and qualitative research. See Kumar, Research Methodology, 29-33.

95 Basic philosophy carries basic and applied research; the objectives of a study can be exploratory, explanatory, and descriptive; the methodology of any study can be quantitative or qualitative; the time period of a study varies between cross-sectional or longitudinal; the analysis may be carried out at the levels of individual, group, organization, and society. See Sait Gürbüz and Faruk Şahin, Sosyal Bilimlerde Araştırma Yöntemleri (Ankara: Seçkin Yayıncılık, 2016), 94.

${ }_{96}$ Descriptive study attempts to systematically describe a situation, problem, phenomenon, service, or program, or provides information. Exploratory research is undertaken with the objective either to explore an area about which little is known or to investigate the possibilities of undertaking a particular research study. Explanatory research attempts to clarify why and how there is a relationship between aspects of a situation or phenomenon. See Kumar, Research Methodology, 8-10. 
archived records/documents, datasets, and open sources; and last, the quantitative and qualitative techniques were part of the data analysis. ${ }^{97}$ The methodological characteristics of the dissertations and articles are shown in Table 1 below.

\begin{tabular}{|c|c|c|c|c|c|}
\hline \multirow{2}{*}{\multicolumn{2}{|c|}{ Methodological Considerations }} & \multirow{3}{*}{$\begin{array}{c}\begin{array}{c}\text { Dissertations } \\
(\mathrm{N}=44)\end{array} \\
\mathbf{2 2} \mathbf{( 5 0 \% )}\end{array}$} & \multicolumn{3}{|c|}{ Articles } \\
\hline & & & $\begin{array}{l}\text { TR Dizin } \\
(\mathrm{N}=112)\end{array}$ & $\begin{array}{c}\text { WoS } \\
(\mathrm{N}=86)\end{array}$ & $\begin{array}{c}\text { Total } \\
(\mathrm{N}=198)\end{array}$ \\
\hline \multirow{3}{*}{ Objectives } & Exploratory & & $35(31 \%)$ & $43(50 \%)$ & $78(39 \%)$ \\
\hline & Descriptive & $17(39 \%)$ & $63(56 \%)$ & $19(22 \%)$ & $82(42 \%)$ \\
\hline & Explanatory & $5(11 \%)$ & $14(13 \%)$ & $24(28 \%)$ & $38(19 \%)$ \\
\hline \multirow{9}{*}{$\begin{array}{c}\text { Data Collection } \\
\text { Tools }\end{array}$} & Questionnaire & $3(7 \%)$ & $2(--)$ & $3(--)$ & $5(--)$ \\
\hline & Observation & $1(2 \%)$ & $0(--)$ & $1(--)$ & $1(--)$ \\
\hline & Interview & $10(22 \%)$ & $5(0.4 \%)$ & $2(--)$ & $7(0.4 \%)$ \\
\hline & Life story & $4(9 \%)$ & $0(--)$ & $0(--)$ & $0(0)$ \\
\hline & Archived documents & $2(5 \%)$ & $7(0.6 \%)$ & $2(--)$ & $9(0.5 \%)$ \\
\hline & Judicial documents & $13(30 \%)$ & $9(0.8 \%)$ & $4(0.5)$ & $13(0.5 \%)$ \\
\hline & Datasets & $2(5 \%)$ & $28(25 \%)$ & $30(35 \%)$ & $58(29 \%)$ \\
\hline & Open sources & $30(68 \%)$ & $74(66 \%)$ & $39(45 \%)$ & $113(57 \%)$ \\
\hline & Tools more than one & $16(36 \%)$ & $1(--)$ & $10(12 \%)$ & $11(0.5 \%)$ \\
\hline \multirow{3}{*}{$\begin{array}{l}\text { Data Analysis } \\
\text { Techniques }\end{array}$} & Qualitative & $34(77 \%)$ & $84(75 \%)$ & $42(49 \%)$ & $126(64 \%)$ \\
\hline & Quantitative & $2(5 \%)$ & $16(14 \%)$ & $39(45 \%)$ & $55(28 \%)$ \\
\hline & Quantitative and qualitative & $8(18 \%)$ & $12(11 \%)$ & $5(6 \%)$ & $17(9 \%)$ \\
\hline
\end{tabular}

Regarding research objectives, doctoral candidates preferred exploratory researches, while the article authors chose to publish in descriptive and exploratory manners. Since exploratory studies generate new ideas or conjectures - which is expected from $\mathrm{PhD}$ candidates - this finding is not surprising. Descriptive studies share a big portion (42\%) of articles, and second $(39 \%)$ in dissertations.

Exploratory and descriptive studies aim to fill the gap in any field by setting the scene and by identifying the main forces at work ${ }^{98}$ that are not well known or researched. These two research purposes encourage scholars to study cases and analyze them qualitatively. Indeed, we found that $45 \%$ of the articles and $32 \%$ of the dissertations were carried out by the case study method.

Suprisingly, there are fewer dissertations (11\%) and articles (19\%) that attempt to explain a situation or a problem by examining the relations between the variables from an explanatory perspective. Comparing the articles in TR Dizin to the articles in internationally indexed journals (WoS), we see that explanatory and exploratory approaches dominate international articles, at $78 \%$. This finding may be the consequence of the standard put forward by the internationally academic journals.

${ }^{97}$ It should be noted that the classifications used in this article do not have rigid boundaries but resilient ones because different techniques and varied tools can be used in one study. The most dominant methodological characteristic of the study was taken into consideration. The questionnaires, observations, and interviews were classified as primary data collection tools, while the others were classified as secondary.

98 Silke, "The Devil You Know". 
Explanatory study is the highest academic level of understanding a subject. Its particular aim is to explain what happened, what is happening, and what will happen. ${ }^{99}$ In this study, we found that explanatory studies were infrequently practiced comparing to other types. An important reason for this result is that there is not sufficient accumulated knowledge in the terrorism field. The other reason, to be explained below, is that there is a lack of reliable and valid data; explanatory research mostly requires hypothesis testing, and that requires quantitative data collected from the field.

In other findings, only 14 of the doctoral dissertations depended upon primary data collection tools and 30 dissertations benefitted mostly from secondary sources. ${ }^{100}$ The authors of articles also collected data mostly from secondary sources, with primary sources used only in 13 articles. In addition, most of the studies were performed with a literature review of open sources, such as published articles, books, and web searches. These findings are significant because they signify that Turkish terrorism studies are almost solely based on secondary sources and literature reviews, which Silke calls "integrators of literature." 101

Indeed, this finding was reiterated in the interviews; participants agreed that "academic studies have methodological weaknesses." Additionally, to the question of "What are the methodological problems in terrorism studies in Turkey?" most participants responded with "not having analyses based on data" and "difficulties of data collection." Although there are multiple international databases on terrorism-related events, which are preferred by the authors of articles in internationally indexed journals, these databases have limitations. They suffer from different definitions of terrorism, missing values on dates and events, and being hinged on open sources. For this reason, there is no reliable database based on official documents that compile and classify terrorist attacks committed in Turkey. Further, the security institutions holding this kind of information have not been sharing it with the public for secrecy reasons.

The problems with collecting useful data reverberate through the analysis techniques. A lack of coherent datasets inhibits the quality and practicability of quantitative analysis. Thus, qualitative analysis techniques were used in 34 dissertations (77\%) and 126 articles (64\%), while quantitative analysis was used just in two dissertations (5\%) and 55 articles (28\%), the latter mostly in the articles from internationally indexed journals. Further, some studies (18\% of dissertations and $9 \%$ of articles) employed quantitative and qualitative analysis concurrently.

It is also noteworthy that quantitative analysis was mostly used by researchers with an academic background in Economics. When we look at these techniques in detail, descriptive statistics (16\% of dissertations and $11 \%$ of articles) and inferential statistics (9\% of dissertations and $22 \%$ of articles) in quantitative analyses, as well as content and discourse analyses in qualitative techniques, were prominent. This fact is congruent with the findings derived from the research objectives and data collection tools, which all point to the lack of analytical studies.

In addition to these weaknesses, there are also some basic methodical problems in the articles and dissertations. For instance, $50 \%$ of the articles did not state the aim of the study. Further, there are no keywords in about $14 \%$ of articles in TR Dizin and in 44 doctoral

\footnotetext{
99 Silke, "The Devil You Know".

${ }^{100}$ In 15 doctoral dissertations and 11 articles, the authors used both primary and secondary sources.

${ }^{101}$ Silke, "The Devil You Know".
} 
dissertations out of 75 examined. This finding was unanticipated because such statements are common and mandatory procedure for academic publications. These problems indicate that writing techniques and screening procedures for journals in TR Dizin need to be improved.

\section{Conclusion}

Although international terrorism studies is showing signs of becoming a stand-alone discipline, our examination of Turkish terrorism studies revealed that there are several impediments for this field specifically. The first is that it has a multi-disciplinary character, bearing largely other disciplines' approaches, concepts, and theories. The field does not have its own researchers, authors, or supervisors of dissertations and interviews, and most articles were written by one-time authors. Due to these factors, Turkish terrorism studies tend to lack the distinct terminology and theoretical accumulation created by scholars of international terrorism studies. These problems seem to be related to the field's multidisciplinary aspect, such that it does not have an interdisciplinary perspective or is a stand-alone discipline.

Terrorism research is intrinsically value laden. Although there is not much evidence, we suspect from the comments of our interviewees, that authors of terrorism studies have been affected by their own emotions, values, and identities. For this reason, they likely hesitate to touch upon 'sensitive issues'. However, this issue is not specific to Turkish terrorism studies; it is argued that international terrorism studies also reflects this vulnerability.

Regarding methodology, a significant problem of the terrorism research field is that the studies are mostly composed of literature reviews or are based on secondary sources. The barriers to reaching primary sources result in the unsatisfying analysis of research problems. Moreover, there is no compiled comprehensive terrorism dataset for terrorist attacks committed in Turkey. These last two issues likely impede the quantity of research focusing on terrorism in Turkey, and, in contrast to the aim of science, which is to produce new knowledge, the area's methodological weaknesses contribute to the reproduction of already-known facts.

These problems should be appraised as opportunities to develop the field. For example, practitioners could aim to produce collaborative papers with academics from different disciplines. Another opportunity is to develop a dataset comprising terrorist attacks in Turkey by synchronizing official documents and open sources to facilitate reliable data-based analysis. Further, an academic journal with rigorous screening and editorial policy could consolidate studies on terrorism.

Nevertheless, problems such as the field's multidisciplinary character, transient authors, a lack of reliable and valid datasets, the dearth of primary sources and quantitative analyses are among the significant problems mentioned by many international studies on terrorism. The international field has been striving to solve these problems, for instance, by founding comprehensive datasets and by the growing numbers of analytical studies. When considered from this point of view, it can be argued that Turkish terrorism studies has been experiencing difficulties faced by the international field almost 20 years ago. Silke's comment on international terrorism studies between 1995 and 2000 could apply Turkish terrorism studies now: "it exits on a diet of fast-food research: quick, cheap, ready-to-hand, and nutritionally dubious." 102 We feel that our study, as a preliminary assessment, can satisfy a need in the 
academic field and can contribute to improving perspectives on strategies for countering terrorism on the ground, which is one of the most important contemporary security threats in Turkey.

\section{Bibliography}

Ackerman, Gary A., and Lauren E. Pinson. "Speaking Truth to Sources: Introducing a Method for the Quantitative Evaluation of Open Sources in Event Data." Studies in Conflict \& Terrorism 39, nos. 7-8 (2016): 617-40.

Aydınl, Ersel, Erol Kurubaş, and Haluk Özdemir. Yöntem, Kuram, Komplo: Türk Uluslararası Illişkiler Disiplininde Vizyon Arayışları. Ankara: Asil Yayın Dağıtım, 2009.

Crenshaw, Martha. "Current Research on Terrorism: The Academic Perspective." Studies in Conflict and Terrorism 15, no. 1 (1992): 1-11.

. "The Psychology of Terrorism: An Agenda for the 21st Century." Political Psychology 21, no. 2 (2000): 405-20.

Creswell, John W., and Dana L. Miller. "Determining Validity in Qualitative Inquiry." Theory into Practice 39, no. 3 (2000): 124-30.

Crozier, Brian. The Rebels. London: Chatto and Windus, 1960.

Demir, Cenker Korhan. Sebeplerinden Mücadele Yöntemlerine Etnik Ayrllıķ̧ı Terörizmin Analizi: PIRA, ETA, PKK. Ankara: Nobel Akademik Yayınc1lık, 2017.

Freedman, Benjamin. "Terrorism Research Centres: 100 Institutes, Programs and Organisations in the Field of Terrorism, Counter-Terrorism, Radicalisation and Asymmetric Warfare Studies." Perspectives on Terrorism 4, no. 5 (2010). Accessed May 13, 2016. http://www.terrorismanalysts.com/pt/index.php/pot/article/view/123/ html.

Gordon, Avishag. "Can Terrorism Become a Scientific Discipline? A Diagnostic Study." Critical Studies on Terrorism 3, no. 3 (2010): 437-58.

. "Terrorism as an Academic Subject after 9/11: Searching the Internet Reveals a Stockholm Syndrome Trend." Studies in Conflict and Terrorism 28, no. 1 (2005): 45-59.

_ . "Terrorism and Knowledge Growth: A Databases and Internet Analysis." In Research on Terrorism: Trends, Achievements and Failures, edited by Andrew Silke, 104-18. London: Frank Cass, 2004.

_. "Terrorism and the Scholarly Communication System." Terrorism and Political Violence 13, no. 4 (2001): $116-24$

—. "Transient and Continuant Authors in a Research Field: The Case of Terrorism." Scientometrics 72, no. 2 (2007): 213-24

Guest, Greg, Arwen Bunce, and Laura Johnson. "How May Interviews Are Enough? An Experiment with Data Saturation and Variability." Field Methods 18, no. 1 (2006): 59-82.

Gurr, Ted Robert. "Empirical Research on Political Terrorism: The State of the Art and How It Might Be Improved." In Current Perspectives on International Terrorism, edited by R.O. Slater and Michael Stohl, 115-54. London: Macmillan, 1988.

Gürbüz, Sait, and Faruk Şahin. Sosyal Bilimlerde Araştırma Yöntemleri. Ankara: Seçkin Yayıncılık, 2016.

Hülsse, Rainer, and Alexander Spencer. "The Metaphor of Terror: Terrorism Studies in Constructivist Turn." Security Dialogue 39, no. 6 (2008): 571-92.

Jackson, Richard. "The Epistemological Crisis of Counterterrorism." Critical Studies on Terrorism 8, no. 1 (2015): $33-54$.

—. "The Study of Terrorism 10 Years after 9/11: Successes, Issues, Challenges." Uluslararası İlişkiler 8, no. 32 (2012): 1-16.

Jackson, Richard, Marie Breen Smyth, and Jeroen Gunning, ed. Critical Terrorism Studies: A New Research Agenda. London: Routledge, 2009. 
Jackson, Robert. “Constructing Enemies: 'Islamic Terrorism' in Political and Academic Discourse.” Government and Opposition 42, no. 3 (2007): 394-426.

Kumar, Ranjit. Research Methodology. London: Sage Publications, 1999.

Lentini, Pete. "Review Essay-Understanding and Combatting Terrorism: Definitions, Origins and Strategies." Australian Journal of Political Science 43, no. 1 (2008): 133-40.

Lum, Cynthia, Leslie W. Kennedy, and Alison Sherley. "Are Counter-Terrorism Strategies Effective? The results of the Campbell systematic review on counter-terrorism evaluation research." Journal of Experimental Criminology 2, no. 4 (2006): 489-516.

Merari, Ariel. “Academic Research and Government Policy on Terrorism.” Terrorism and Political Violence 3, no. 1 (1991): 193-202.

Ranstorp, Magnus, ed. Mapping Terrorism Research: State of the Art, Gaps and Future Direction. London: Routledge, 2006.

"Mapping Terrorism Studies after 9/11: An Academic Field of Old Problems and New Prospects." In Critical Terrorism Studies, edited by Richard Jackson, Marie Breen Smyth, and Jeroen Gunning, 13-33. London: Routledge, 2009.

Rapoport, David C. "The Four Waves of Rebel Terror and September 11." In The New Global Terrorism, edited by Charles Kegley, 36-52.New Jersey: Pearson, 2008.

Reid, Edna O. F. "Evolution of a Body of Knowledge: An Analysis of Terrorism Research.” Information Processing and Management 33, no. 1 (1997): 91-106.

Reid, Edna, and Hsinchun Chen. "Domain Mapping of Contemporary Terrorism Research." In Terrorism Informatics: Knowledge Management and Data Mining for Homeland Security, edited by H. Chen, E. Reid, J. Sinai, A. Silke and B. Ganor, 3-26. New York: Springer, 2008.

Richards, Anthony. "Conceptualizing Terrorism.” Studies in Conflict \& Terrorism 37, no. 3 (2014): 213-36.

Ross, Jeffrey Ian. "Taking Stock of Research Methods and Analysis on Oppositional Political Terrorism." The American Sociologist (2004): 26-37.

Sageman, Marc. "The Stagnation in Terrorism Research.” Terrorism and Political Violence 26 (2014): 565-80.

Satana, Nil S., Molly Inman, and Johanna Kristin Binnir. "Religion, Government Coalitions, and Terrorism." Terrorism and Political Violence 25, no. 1 (2013): 29-52.

Schmid, Alex P. “Comments on Marc Sageman's Polemic “The Stagnation in Terrorism Research.” Terrorism and Political Violence 26, no. 4 (2014): 587-95.

_. "Introduction." In Schmid, The Routledge Handbook, 1-37.

—. "The Definition of Terrorism." In Schmid, The Routledge Handbook, 39-98.

. "The Literature on Terrorism." In Schmid, The Routledge Handbook, 457-74.

. Political Terrorism: A Research Guide to Concepts, Theories, Data Bases and Literature. Amsterdam: North-Holland Publishing, 1984.

- ed. The Routledge Handbook of Terrorism Research. London: Routledge, 2011.

Schmid, Alex P., and Albert J. Jongman. Political Terrorism: A New Guide to Actors, Authors, Concepts, Data Bases, Theories, and Literature. London: Transaction Publishers, 1988.

Shepherd, Jessica. "The Rise and Rise of Terrorism Studies." The Guardian, July 3, 2007. Accessed March 11, 2016. http://www.theguardian.com/education/2007/jul/03/ highereducation.research.

Sil, Rudra, and Peter Katzenstein. "Analytical Eclecticism in the Study of World Politics: Reconfiguring Problems and Mechanisms across Research Traditions.” Perspectives on Politics 8, no. 2 (June 2010): 411-31.

Silke, Andrew. "The Devil You Know: Continuing Problems with Research on Terrorism." Terrorism and Political Violence 13, no. 4 (Winter 2001): 1-14.

—. "The Impact of 9/11 on Research on Terrorism." In Mapping Terrorism Research, edited by Magnus Ranstorp, 76-93. London: Routledge, 2006. 
"The Road Less Travelled: Recent Trends in Terrorism Research." In Research on Terrorism: Trens Achievements and Failures, edited by Andrew Silke, 186-213. London: Frank Cass, 2004.

Stampnitzky, Lisa. Disciplining Terror. Cambridge: Cambridge University Press, 2013.

- "Disciplining an Unruly Field: Terrorism Experts and Theories of Scientific/Intellectual Production." Qual Sociol 34, no. 1 (2010): 1-19.

Thorton, Thomas P. "Terror as a Political Agitation." In Internal War: Problems and Approaches, edited by Harry Eckstein, 71-91. New York: The Free Press of Glencoe, 1964.

Toros, Harmonie, and Jeroen Gunning. "Exploring A Critical Theory Approach to Terrorism Studies.” In Critical Terrorism Studies, edited by Richard Jackson, Marie Breen Smyth, and Jeroen Gunning, 87-108. London: Routledge, 2009.

Walter, Eugene V. "Violence and The Process of Terror." American Sociological Review 29, no. 2 (Spring 1964): 48-257.

Weinberg, Leonard, Ami Pedahzur, and Sivan Hirsch-Hoefler. "The Challenges of Conceptualizing Terrorism." Terrorism and Political Violence 16, no. 4 (2004), 777-94.

Zulaika, Joseba. "Drones, Witches and Other Flying Objects: The Force of Fantasy in US Counterterrorism." Critical Studies on Terrorism 5, no. 1 (2012): 51-68. 
